\title{
Access to subsidised medicines, cost of medicines and health outcomes: exploring general practitioners' perceptions and experiences
}

\author{
Zaheer-Ud-Din Babar*, Abdul Ali, Christine Kim, James Mcintosh, Malaika Samuel Namdas, Erica Lourdes Rodrigues \\ , Komal Vallabh, Anne Rew
}

From 3rd International PPRI Conference 2015: Pharmaceutical Pricing and Reimbursement Policies: Challenges Beyond the Financial Crisis

Vienna, Austria. 12-13 October 2015

\section{Objectives}

The general aim of this study was to evaluate general practitioners' perceptions, knowledge and experiences regarding medicines' cost and subsidy in New Zealand.

\section{Methods}

A quantitative cross-sectional study, with postal questionnaires, was conducted to survey $700 \mathrm{New}$ Zealand general practitioners (GPs) registered with the Medical Council of New Zealand. A total of 180 GPs participated, which is $25.7 \%$ of the random sample. GPs' perceptions, knowledge and experiences were measured.

\section{Results}

A total of 180 questionnaires were returned and used in the analysis. Of all respondents, only $12 \%$ were able to correctly identify the subsidy status of all six medicines. Eighty three percent were of the opinion that the Pharmaceutical Management Agency of New Zealand (PHARMAC) considers its budget as the most important factor when deciding to fund medicines. Only a few participants were able to correctly identify strategies used by PHARMAC. Concerns were raised over the special authority criteria, with $55 \%$ agreeing that health outcomes would improve if the criterion was made more relaxed. Fifty-three percent of the GPs agreed that a fully funded medicine improves compliance while $51 \%$ agreed or strongly agreed that the increase in medicine co-payment has had a negative effect on patient's access to medicine. Most GPs were neutral to the statements that health outcomes would improve if

* Correspondence: z.babar@auckland.ac.nz

School of Pharmacy, University of Auckland, Private Mail Bag 92019, Auckland, New Zealand
Cite this article as: Babar et al: Access to subsidised medicines, cost of medicines and health outcomes: exploring general practitioners' perceptions and experiences. Journal of Pharmaceutical Policy and Practice 2015 8(Suppl 1):O6.

Submit your next manuscript to BioMed Central and take full advantage of:

- Convenient online submission

- Thorough peer review

- No space constraints or color figure charges

- Immediate publication on acceptance

- Inclusion in PubMed, CAS, Scopus and Google Scholar

- Research which is freely available for redistribution 